\title{
Does Capital Structure Affects Firms' Performance in Ghana? Panel Data Analysis
}

\author{
Dr. John MacCarthy ${ }^{1} \&$ Dr. Mrs. Helena Ahulu ${ }^{2}$ \\ ${ }^{1}$ Accounting Department, University of Professional Studies, Accra, Ghana \\ ${ }^{2}$ HOD, Accounting Department, University of Professional Studies, Accra, Ghana \\ Correspondence: John MacCarthy, University of Professional Studies, Accra, Ghana. E-mail: \\ maccarthy.john@upsamail.edu.gh
}

Received: July 17, 2019

Accepted: October 12, 2019

Online Published: October 14, 2019

doi:10.5430/afr.v8n4p131

URL: https://doi.org/10.5430/afr.v8n4p131

\begin{abstract}
This paper examines the effect of capital structure on the firms' performance. The study collected data from seventeen firms listed on the Ghana Stock Exchange from 2009 to 2018. A quantitative research technique is used to collect data to test two hypotheses. Panel data regression is employed to determine the effect of capital structure on firms' performance. The study revealed that short-term debt and total debt accounted for $67 \%$ and $76.3 \%$ respectively of capital used to finance the operations for the period. Furthermore, the study revealed that there is significant and negative relationship between capital structures and firms' performance. The study concludes that firms should minimise the use of debt capital and rather concentrate on equity capital to finance their operations. The study recommends that firms should increase sales and invest in tangible assets to maximise the firms' performance.
\end{abstract}

Keywords: capital structure, firms, profitability, short-term debt, total debt

\section{Introduction}

The choice behind particular capital source used to finance business operations is still a puzzle (Abeywardhana, 2017). Many owners believed that managers used debt capital in order to take advantage of tax shield from interest, as advocated by the trade-off theory based on optimum capital structure. The goal of every manager is to maximise shareholders' value for the owners and capital structure decision is one of the means firms use to achieve this objective (Akinyomi \& Adebayo, 2013). This position espoused by the trade-off theorist, based on optimum capital structure theory, argues that optimum capital will maximise shareholders' value or minimise cost of capital. This position is challenged and proven empirically that capital structure is negatively related to firms' performance (Nenu, Ventila \& Gherghina, 2018).

Capital structure decisions are among very important strategic decisions firms make because they affect firms performance. Capital structure is a combination of debt and equity capital needed to finance the firms' operations (Azhagaiah \& Gavoury, 2011). A wrong deployment of capital structure decision may lead to the firm's failure and eventually end in bankruptcy while appropriate source of capital will maximise shareholders' value. This implies that inappropriate capital structure decision may lead to bad consequences for firms, such as very high cost capital, which can threaten the very survival of these firms. Many firms have collapsed due to uncontrolled use debt of capital to finance firms' operations. This implies that firms can maximise their shareholders' value when they use appropriate capital mix from either debt capital or equity capital or combination of both debt and equity capital.

Different firms use different sources of capital to finance their operations. They use various sources of capital available for firms to finance their operations are short-term debt, long-term debt, preference shares, ordinary shares and retained earnings. Capital structure is a mixture of these different capitals to finance the firms' operations. Appropriate capital structure that would minimise the cost of capital and at the same time maximise the firms' performance is known as optimum capital structure. Optimum capital structure varies from institution to institution and is based on the level of sales, earnings' stability, assets structure and borrowing power of the firms (Yegon, Cheruiyot \& Cheruiyot, 2014).

Many managers prefer the use of debt capital to equity capital because debt capital requires less control by creditors when compare to control by owners from equity capital. For that matter, many managers sometimes overlook the disadvantages associated with debt capital needed to finance their operations. Even though the debt capital provides 
some benefits in the form of tax shield to the firms, it increases financial risks of firms due to default risk. Default risk is the risk that the firm is unable to service their debts and obligations within specified time periods (Shubita \& Alsawalhah, 2012).

There are several theories on capital structure such as trade-off theory, pecking order theory, agency cost theory and market signal hypothesis. All these theories try to explain the basis on which firms make capital structure decisions. Proponents of Trade-off theory argue that optimum capital structure will maximise the firm's value or minimise cost of capital while opponents of trade-off theory, such as pecking order theory, agency theory and market signal theory have challenged trade-off theory and explain that debt capital is introduced into equity capital based on behaviour characteristics such as hierarchy and continuous decision over time. Capital structure decisions depend of the firm's unique characteristics (Faulkender \& Petersen, 2005).

\section{Literature Reviews}

The section reviews recent literature on capital structure and firms' performance. The reviews is organised into capital structure theories and empirical evidence on capital structure and firm's performance.

\subsection{Capital Structure Theories}

Modigliani and Miller (1958) opened up capital structure theory espoused earlier by Duran (1952) and referred to it as capital structure irrelevant theory. The theory generated a lot of controversies from researchers. Irrelevant capital structure argues that whatever capital is employed by the firm is irrelevant. Whether equity capital or debt capital is used by the firm will eventually be the same. The theory is based on some assumptions that are and cannot hold true in the financial markets. The assumptions used by the theory are: that the capital market is perfect; that there is absence of taxes; that there are no bankruptcy and transaction costs; that all investors have the same information as management have about a firm's future investment and investor's opportunities. The opponents of capital structure irrelevant theory argue that the financial markets are imperfect: transactional costs, taxes, inflation and uncertainty in the market place operated by entities in the real world. These criticisms become the basis for many further theories on capital structure to be developed based on unrealistic assumptions. Later, Miller and Modigliani (1963) relaxed some of the assumptions especially on the absence of taxes, and concluded that debt capital would increase a firm's profitability due to tax shield advantage. Other capital structures theories such as trade-off theory, signalling theory, pecking order theory and marketing timing theory were espoused later to explain the capital decisions of firms.

\subsubsection{Trade-off Theory}

Trade-off capital structure theory is connected to Miller and Modigliani theory on capital structure, which is considered to be among the oldest theories on capital structure. The theory argues that optimum capital structure should maximise the firm's performance or minimise the cost of capital. The theory takes into consideration the advantages and disadvantages that a firm accrues from incorporation of debt capital into equity capital to finance firm's operations. Trade-off theory stresses that firm should select an optimal capital structure that maximises the firm's value by minimising costs of prevailing market imperfections (Sheikh \& Wang, 2010). Under the trade-off theory firms should determine their preferred leverage ratio by calculating the advantages of tax shield and the disadvantage of financial distress cost. The financial distress cost includes direct and indirect costs from bankruptcy. The direct cost contains lawyers' and accountants' fees, professional fees, and the value of the managerial time spent in administering bankruptcy. Indirect cost includes the loss of revenue and profits and possibly the inability of the firm to obtain credit or to issue securities under burdensome terms.

The trade-off theorist posits that when capital structure is based optimal capital structure, it will maximize the firm's value and minimize the cost of capital; it is of the belief that the firm's value cannot be the same at different levels of capital structure (Chakraborty, 2010). Other researchers investigated, revealed and concluded that there were negative relationships between capital structures and firm's performance (Beattie et al., 2006; Dahlstrom \& Persson, 2010). This inconsistent relationship between capital structure and firm's performance is due to complexity and different tax benefits enjoyed by firms (Graham, 2000).

\subsubsection{Pecking Order Theory}

This theory argues that the capital structure of a firm is driven by the needs for financing new investments and not by the existence of an optimal debt level and that a firm makes capital structure decision based on the hierarchy of internal sources, then debt capital and equity capital in that order. Pecking order theory argues that managers give priority to source of capital that requires least amount of information to be given. Therefore, most profitable firms tend to be least indebted. The theory explains why the bulk of unprofitable firms are burdened with external debt; and why more profitable firms borrow less; not because their target debt ratio is low (Fama \& French, 2002). The 
Pecking order theory is a behavioural characteristic of managers to explain how firms finance their business with capital needed. This shows that firms only use equity capital after they have exhausted internally generated funds, short term debt and long term debt. The pecking order theory posits that the entity use internally generated funds from retained earnings first, followed by debt capital and if further financing is needed then equity capital should be used. The preference order in deciding the source of finance is dependent on the sources of finance as in this order: Internal source like retained earnings; debt and equity.

Hamberg (2001) conducted a survey on the preference source of capital used by managers and described eight preference order of capital sources (p. 216):

Internally generated source

Already approved bank credits (short-term debt)

Bank loans from current main lender (short-term debt)

Issue of bonds (Long term debt)

Issue of convertible securities (Long term debt)

Issue of preference stock (Long term debt)

Issue of ordinary shares to current owners (Equity capital)

Issue of ordinary shares to new investors (Equity capital)

Dahlstrom and Persson (2010) conducted a study on capital structure decisions of firms and concluded that most firms followed pecking order theory on capital structure because it was costlier to issue equity capital than debt capital and that firms preferred source of capital that requires less control and information. Abor (2005) and Fama and French (2002) conducted a study on Pecking order theory and concluded that capital structures were negatively related with firm's performance.

\subsubsection{Agency Cost Theory}

Agency cost theory was introduced by Jensen (1986) as basis for capital structure decision by managers. The theory argues that it is impossible for managers to act without conflict of interest. Agency theory is about the relationship between principal (i.e., owners) and agents (i.e., managers) in the running of the business. Agency theory recognizes that sometimes managers do not act in the best interest of owners. This creates conflict of interest situation between the principals and agents in the running of the firm. Conflict of interest happens in some of the financial decisions taken by managers at the expense of the owners. Example of conflict of interest happens when the best capital should be equity capital but managers go for debt capital as espoused by pecking order theory. Managers have not acted in the best interest of the owners best resorted to raise capital from a source that requires least control rather than to the best benefit to the owners. Again, due to agency theory, conflict managers will prefer to invest free cash flow into new project rather than pay dividend to shareholders in order to expand and grow their firms.

Many a times, managers are motivated to borrow to expand and grow the business not because it is the decision for the firm but to rather boost their personal career growth. Some of the debts can create high cost to the firm and sometimes financial distress, leading to bankruptcy at the expense of the owners. This implies that managers sometimes take unnecessary risk to borrow and buy assets to expand the firm at the expense of the owners. Agency theory explains that managers may act irrationally overconfident and take unnecessary risk which sometimes goes against the owners because of their personal motive. Agency theory creates the problem of information asymmetry, adverse selection, and moral hazard. To avoid the problem associated with agency theory, it is important that the shareholders monitor the actions and inactions of managers to safeguard their capital. One of the problems associated with agency theory of capital structure is agency cost. This is in form of bankruptcy costs, monitoring of directors, and compensation contracts etc. According to Iavorskyi (2013), agency costs arise from agency conflict between managers and shareholders. To resolve the agency cost problem associated with capital structure, there is the need to incorporate monitoring and control into capital structure theory.

Ideally, the firm will have to incorporate agency cost into the trade-off theory of the tax advantage that comes from tax shield from interest against the disadvantage of costs of bankruptcy cost (Jensen, 1986). Chen and Chen (2012) conducted a study on agency theory of capital and concluded that capital structure was negatively related to firm's performance. Hence agency theory is closely connected to pecking order theory which argues that firms prefer to use internally generated fund rather than external funds. 


\subsubsection{Market Timing Theory}

Market timing theory challenges that there is no optimal capital structure and that capital structure decisions change with times based on fluctuation in equity value (Baker \& Wurgler, 2002). Market timing theory of capital structure argues that managers do not care about the composition of debt capital and equity capital structure mix but rather about fluctuation of equity price on the financial market. The theory assumes that firms sell equity capital whenever they perceived equity prices are over-valued and repurchased equity when they perceived that equity price is under-valued. The theory argued that firms issuance of equity capital is dependent on the fluctuation of the share price in the financial market. One of the problems associated with agency theory is the problem of information asymmetry. Information asymmetry occurs when the agents have more information than owners of the firms and control the information related to the firm to their advantage.

Many a times, managers have information ahead of owners or investors and try to use this information to control the issuance of equity capital in the market. This implies that in corporate finance, "market timing" refers to the practice by which firms issue equity capital based on market value of share price. Therefore, managers control information to the disadvantage or advantage of the market timing of the issuance of equity capital to the market. The most compelling advocates for the market timing theory are Baker and Wurgler (2002) and Mostafa and Boregowda (2014), who argues that a firm's capital structure is a cumulative outcome of past decisions on capital sources over time. This implies that firms that need equity capital will be determined when there equity is over-valued else they will issue debt capital to finance their operations.

\subsection{Empirical Evidence Relating to Capital Structure and Firms' Performance}

Since the introduction of capital structure by Miller and Modigliani, many researchers have conducted several studies to establish empirically the relationship between capital structure and a firm's performance but outcomes have been mixed and inconclusive. Bedar and Saeed (2013) found a significant positive relationship between capital structure and firm's performance while other researchers found negative relationship between capital structure and a firm's performance (Cassa \& Holmes; Onaolapo \& Kajola, 2010).

\subsection{Summary of Capital Structure Theories}

Firms' capital structure cannot be explained by application of one standard theory but rather from perspective of several theories (Beattie, Goodacre \& Thomson, 2006). Capital structure theory is a cumulative outcome of past attempts to explain the relationship between capital structure and firm's performance (Abeywardhan, 2017).

\section{Method}

This study employed quantitative research method to collect secondary data, analyse the research hypotheses of this study. Descriptive statistics, correlational analysis and panel data regression analysis (i.e., multivariate analysis) are the analytical tools used in this study. The advantage of using panel data analysis instead of normal regression is that it is able to treat the unobserved individual heterogeneity for each of the 17 firms selected and also provide more efficient estimation of the parameters by considering broader sources of variations as well as the dynamic behaviour of the parameters. The analysis is done using stata (i.e., statistics and analysis software) as the software for this study.

\subsection{Sample and Data Research Methods}

The population of firms listed on the GSE are 38. Probability sampling technique involving a multi-stage sampling technique was used to select sample of 17 firms for this study. Firms that do not have 5 years listing gestation are excluded for this study as well as firms categorised as finance and insurance. Data was collected from the financial statements of these firms from 2009 to 2018, giving a total of 170 observations for this study. The sample of 17 firms was determined using Yamane formula.

$$
\mathrm{n}=\mathrm{N} /\left(1+\mathrm{N}\left(x^{2}\right)\right.
$$

\subsection{Research Variables}

Variable is property that takes on different values depending on its relationship with other variables. The three different variables used in this study are dependent variable represented by firm's profitability (i.e., ROE), independent variables represented by capital structures (i.e., STR and TDR) and the control variables represented by specific variables (i.e., Size, Tangibility, Growth and Risk) used in this study. 


\subsubsection{Firms' Performance (i.e., Dependent Variable)}

The firms' performances are reflection of how well the resources of the firms have been utilized for the benefit of their stakeholders (Ogebe, Ogebe \& Alewi, 2013). One of the means of measuring firms' performance is Return on Equity (ROE). The study used ROE to measure the firms' performance instead of ROA because ROE is returns to owners of a firm, hence, the study considered ROE as the most appropriate profit metric for measuring firms' performance. Additionally, ROA is embedded in ROE. Therefore, ROE takes care of returns for both the creditors and owners of the firms. ROE measures how much return is generated on equity capital invested by owners. ROE is expressed in ratio terms as:

$$
\mathrm{ROE}=\text { Net profit after tax/Equity capital }
$$

\subsubsection{Capital Structure Variables (i.e., Independent Variables)}

Capital structure variables are used to determine the effect on firms' performance. The two capital structure variables used in this analysis are Short-term Debt Ratio (STR) and Total debt Ratio (TDR). Each variable is used separately to estimate the effect of firms' performance.

Short-term Debt Ratio (STR): STR represents the short-term debt payable within a year. It comprises of bank overdraft and trade creditors used to settle the short-term obligations of the firm. STR is calculated by dividing total current liabilities over total assets as shown below:

$$
\text { STR }=\text { Current liabilities/Total assets }
$$

Long-term Debt Ratio (LTR): LTR represents the Long-term debt capital payable. It determines the leverage or gearing ratio of the firm. LTR is calculated by dividing long-term debt over total assets as shown below:

$$
\text { LTR }=\text { Long term debt/Total assets }
$$

Total-debt Ratio (TDR): TDR represents total of both Short-term Debt and Long-term Debt used by the firms. A high TDR indicates high leverage level used to finance the firms operations. This ratio is a percentage of the firm's total debt over total assets as shown below:

$$
\mathrm{TDR}=\text { Total debts/Total assets }
$$

\subsubsection{Control Variables (i.e., The Level of the Firm Specific Variables)}

Control variables affect both dependent and independent variables and if not control will affect the outcome of the study. Even though they are not the variables under study, there is the need to control these variables or hold them constant so they do not influence the outcome of the analysis. The control variables used are Size, Tangibility, Growth and Risk.

Size: This represents size of the firm. A firm's size plays very important role in the in this study as it affect both dependent and independent variables and therefore, must be controlled. Large firms have two or more product lines and therefore, able to generate more revenue compare smaller firms. Large firms have more diversified and stable product portfolio than smaller firm. This makes the probability of large firms going into bankruptcy lower when compared to smaller firms (Titman \& Wessel, 1988). Again, large firms are able to attract lower interest cost than smaller firms. Abor and Biekpe (2009) opine that the size of a firm plays an important role in the determination of the firm's capital structure. The size is calculated by taking the logarithms of sales divided over total assets as follows:

$$
\text { Size }=\text { Log (Sales/Total assets) }
$$

Tangibility: Tangibility represents the total value of tangible assets used to generate revenue for the firm. Firms with high amount of tangible assets are in the position to provide collateral to raise debts capital. A firm with large amount of tangible assets is able to borrow at lower interest as they serve as collateral for the firm Again, a firm with large tangible assets hardly goes into bankruptcy, as the creditor will seize the assets and sell to defray its outstanding. Bevan and Danbolt (2002) find a positive relationship between tangibility and long-term debt. Muritala (2012) calculated tangible as total non-current assets minus intangible assets all over total assets as:

$$
\text { Tangibility }=(\text { Total non-current assets- intangible assets }) / \text { Total assets }
$$

Risk: Risk represents financial risk of a firm. Financial risk measures the financial health of a firm which shows whether the firm is financially distressed or not. A firm that is financially risky or distressed cannot attract sufficient capital to finance its operations. At worst, the firm will attract a high interest cost. Firm that is financially risky is more likely to go into bankruptcy afterwards. Altman Z-score is the proxy used to measure financial risk of firms in 
this study. The formula for measuring was determined by Altman (2015) and is calculated using five ratios that can be fetched from firm's annual financial statement.

$$
\mathrm{Z}-\mathrm{Score}=1.2 \mathrm{~A}+1.4 \mathrm{~B}+3.3 \mathrm{C}+0.6 \mathrm{D}+1.0 \mathrm{E}
$$

Where $\quad \mathrm{A}=$ Working Capital/Total Assets

$\mathrm{B}=$ Retained Earnings/Total Assets

$\mathrm{C}=$ Earnings before Interest \& Tax/Total Assets

$\mathrm{D}=$ Market Value of Equity/Total Liabilities

$\mathrm{E}=$ Sales/Total Assets

A score below 1.8 indicates that the firm has a high probability for bankruptcy while a score above 3.0 indicates low risk of bankruptcy. According to Mwangi, Makau and Georgr (2014), there is a positive relationship between financially stable firms' performance.

Growth: Growth represents the rate of growth of the firm. A growing firm is able to generate enough revenue to finance its operation vice versa. A growing firm tend to resort to lesser debt capital to finance its operations. A firm with high sales growth has the ability to affect the capital structure needs of the firm and therefore, a firm generating more sales will need lesser funds or capital to finance the working capital of the firm. Pandey (2007) concluded that growth has positive relationship with firm's performance. Park and Jang (2014) measured the growth using the current year's sales minus last year's sales divided by last year's sales and expressed as percentage change in annual sales.

$$
\text { Growth }=(\text { Current year's sales }- \text { Previous year's sales }) / \text { Previous year's sales }
$$

\subsection{Model Specification}

To estimate the effect of capital structures on firms' performance, the study adopted an econometric model similar to Hamid, Abdullah and Kamaruzaman's (2015) but modified them into two models to assess the effect of STR and TDR on the ROE as shown below:

ROEit $=\beta_{0}+\beta_{1}($ STR $)$ it $+\beta_{2}$ (Size)it $+\beta_{3}$ (Tangibility)it $+\beta_{4}($ Grow $)$ it $+\beta_{5}($ Risk $)$ it + cit $\ldots$ model (1)

ROEit $=\beta_{0}+\beta_{1}($ TDR $)$ it $+\beta_{2}$ (Size)it $+\beta_{3}($ Tangibility $)$ it $+\beta_{4}$ (Grow)it $+\beta_{5}$ (Risk)it $+\varepsilon$ it model (2)

Where:

ROE is the dependent variable use in this study.

STR and TDR are the independent variables use in this study.

Size, Tangibility, Growth, and Risk are the control variables in this study.

$\beta_{1}, \beta_{2}, \beta_{3}, \beta_{4}$ and $\beta_{5}$ are regression coefficients of the equation to be estimated.

$\beta_{0}$ is the parameter of the equation.

$\mathrm{t}=$ is the time series of the study $(\mathrm{t}=1,2,3,4,5,6,7,8,9$ and 10)

$\mathrm{i}=$ is the cross-section (i.e., 17 firms selected from the GSE)

$\varepsilon=$ Unique Error or Error Term

\subsection{Research Hypotheses}

The following two hypotheses were analysed to either accept or reject the null hypotheses of this study so that inference can be made for this study:

H01: There is no significant relationship between Short-term Debt Ratio (STR) and firms' performance (ROE).

H02: There is no significant relationship between Total Debt Ratio (TDR) and firms' performance (ROE).

\section{Results and Discussions}

The data collected has to be organised into suitable variables for the analyses. The descriptive statistics was used to describe the central density of variables used in this analysis. 
Table 1. Descriptive Statistics

\begin{tabular}{lccccc}
\hline Variables & Mean & Std. Dev. & Max & Min & Obs. \\
\hline ROE & 0.068 & 0.246 & -2.530 & 0.675 & 170 \\
STR & 0.670 & 1.649 & 0.049 & 21.126 & 170 \\
LTR & 0.093 & 0.134 & 0.003 & 0.662 & 170 \\
TDR & 0.763 & 1.642 & 0.049 & 21.126 & 170 \\
Size & 0.011 & 0.438 & -2.009 & 0.899 & 170 \\
Tangible & 0.494 & 0.237 & 0.010 & 0.934 & 170 \\
Growth & 0.147 & 0.544 & -1.248 & 2.872 & 170 \\
Risk & 2.400 & 3.299 & -10.537 & 22.035 & 170 \\
\hline
\end{tabular}

Source: Researcher's SPSS version 21 Computation

Table 1 describes the variables using mean and standard deviation of all the variables used. This provides a clearer picture of the contribution of the capital structure variables to firm's performance. The first column of Table 1 shows the means of the variables used in this study. The mean of ROE was $6.8 \%$ for the firm's performance for the firms selected for the 10-year period under study. The mean for the capital structures are $67 \%, 9.3 \%$, and $76.3 \%$ for STR, LTR and TDR respectively. This implies that most of the firms listed relied on short term capital to finance their operations and only $9.3 \%$ of long term capital was used to finance their operations within the period under study. Clearly, this shows that the firms selected over the period have resorted to short term debt to finance their operations from 2009 to 2018. Table 1 exhibits pecking order theory which states that managers prefer capital from sources that require least control. This result of the capital structure statistics are consistent with Abor (2007) who concluded that firms on the GSE preferred short term capital instead of long term capital to finance their operations. Again Frank and Goyal (2003) argue that firms that take capital structure decision based on pecking order theory mostly use debt capital more than equity capital when internal source of funds are not sufficient to finance the operations and expansion. The standard deviation gives an indication of how far away the variables are from the mean. The standard deviation for ROE is $24.6 \%$ which is an indication of wide dispersion from the mean. The standard deviations for STR, LTR and TDR are 1.649, 0.134 and 1.642 respectively. The mean of Risk is 2.407 implies that the selected firms lie in grey zone, and therefore, this study can conclude that the firms selected are not financially distressed.

Table 2. Pearson Correlation Coefficients between the Variables

\begin{tabular}{|c|c|c|c|c|c|c|c|c|c|}
\hline \multicolumn{2}{|l|}{ Variables } & ROE & STR & LTR & TDR & Size & Tangibility & Growth & Risk \\
\hline \multirow[t]{2}{*}{ ROE } & Corr. & 1 & & & & & & & \\
\hline & Sig. & & & & & & & & \\
\hline \multirow[t]{2}{*}{ STR } & Corr. & $-.823^{* *}$ & 1 & & & & & & \\
\hline & Sig. & .000 & & & & & & & \\
\hline \multirow[t]{2}{*}{ LTR } & Corr. & $-.319^{* *}$ & $-.241^{*}$ & 1 & & & & & \\
\hline & Sig. & .000 & .004 & & & & & & \\
\hline \multirow[t]{2}{*}{ TDR } & Corr. & $-.835^{* *}$ & $.997^{*}$ & .296 & 1 & & & & \\
\hline & Sig. & .000 & .000 & . 000 & & & & & \\
\hline \multirow[t]{2}{*}{ Size } & Corr. & .077 & $.195^{*}$ & $-.530^{*}$ & $.171^{*}$ & 1 & & & \\
\hline & Sig. & .319 & .011 & .000 & .026 & & & & \\
\hline \multirow[t]{2}{*}{ Tangibility } & Corr. & $.329^{* *}$ & -.114 & -.595 & -.149 & .547 & 1 & & \\
\hline & Sig. & .000 & .141 & .000 & .053 & .000 & & & \\
\hline \multirow[t]{2}{*}{ Growth } & Corr. & .133 & .045 & -.078 & .042 & .206 & $.215^{* *}$ & 1 & \\
\hline & Sig. & .085 & .556 & .354 & .589 & .007 & .005 & & \\
\hline \multirow[t]{2}{*}{ Risk } & Corr. & $.396^{* *}$ & $-.261^{*}$ & $-.289^{*}$ & -.281 & .139 & $.172^{*}$ & .122 & 1 \\
\hline & Sig. & .000 & .001 & .000 & .000 & .071 & .025 & .113 & \\
\hline
\end{tabular}

**. Correlation is significant at the 0.01 level (2-tailed).

*. Correlation is significant at the 0.05 level (2-tailed).

Source: Researcher's Stata version 15 Computation 
The regression was carried out on the assumption that there were correlations between the independent variables and dependent variable used in this study.

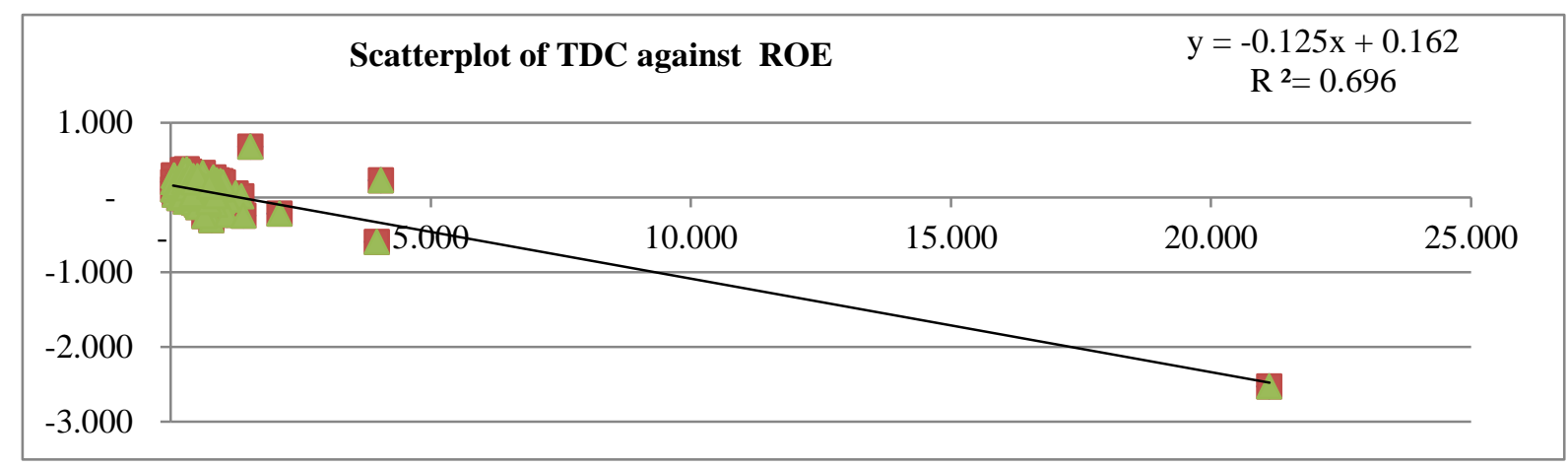

Figure 1. Scatterplot of TDC against ROE

It is important to examine that the models fitted the data for the analysis. Because the study used panel dataset, the following assumptions: linearity, normality, multicollinearity and endogeneity were tested in order to determine the reliability of the regression results. The study employed these diagnostic tools: Scatterplot, Shapiro-Wilk, Multicollinearity and Hausmen test. They were used to provide the assurance that the basic assumptions underlying panel data regression were not violated. Linearity assumption requires that the relationship between the dependent and independent variables should be in linear design. The study used scatterplot to plot the capital structure variables TDR and STR on ROE. Figure 1 shows the scatter plot of TDC on ROE in a linear design and shows that relationship between TDC on ROE is linear.

Figure 2 shows the result of scatter plot of STC against ROE. Even though, some outliers were detected in the linear relationship but the TDC and STC variables provide a satisfactory degree of linearity.

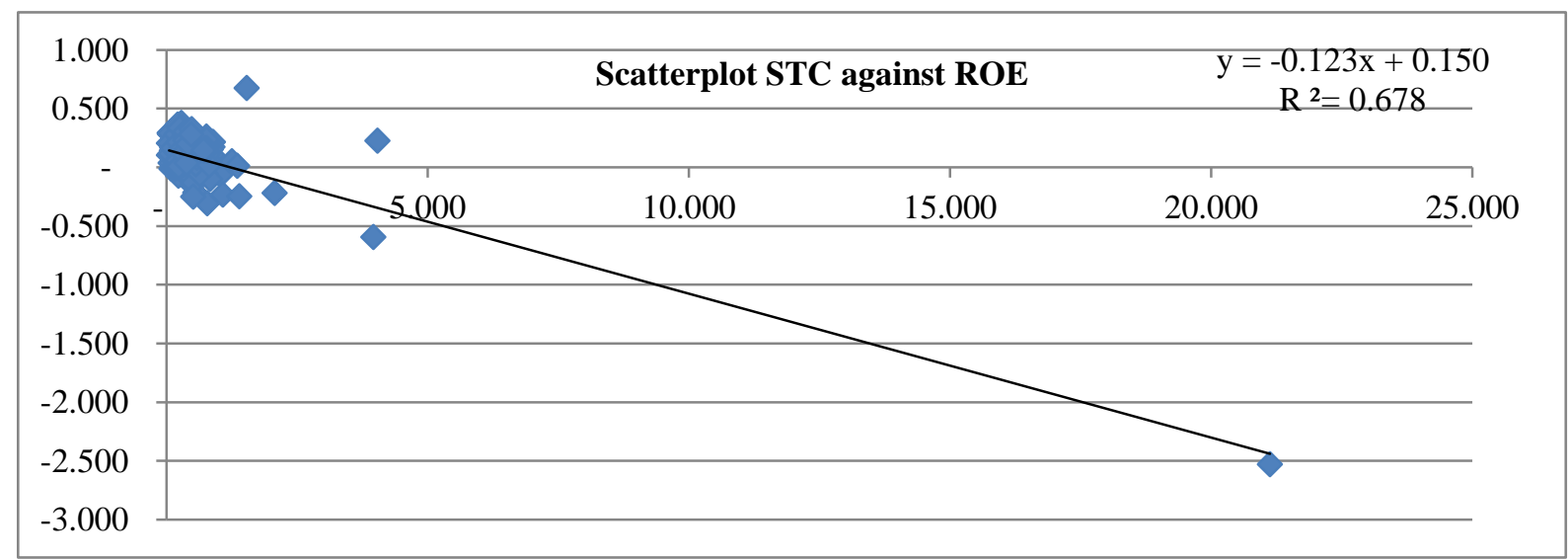

Figure 2. Scatterplot of STC against ROE

The Shapiro-Wilk test is used to test the assumption that dependent data are normally distributed. Table 3 shows the result obtained from Shapiro-Wilk test were normally distributed. The p-value is greater than 5\% (i.e., p<0.05), therefore, the assumption that data should be normally distributed is not rejected. When data is normally distributed, it means the outcome from the regression analysis will provide a valid conclusion for the relationship between the capital structure and the firm's performance for this study.

Table 3. Shapiro-Wilk's to Test Normality Distribution

\begin{tabular}{lllllll}
\hline \multicolumn{3}{c}{ Kolmogorov-Smirnov $^{\mathrm{a}}$} & \multicolumn{5}{c}{ Shapiro-Wilk } \\
\multirow{3}{*}{ Model } & Statistic & $\mathrm{df}$ & Sig. & Statistic & df & Sig. \\
& .214 & 170 & .000 & .529 & 170 & .000 \\
\hline
\end{tabular}

Source: Researcher's SPSS version 21 Computation 
Variance Inflation Factor (VIF) method is used to test the presence of multicollinearity. Multicollinearity is used to check correlations between the independent and control variables used for this study.

Table 4. Test of Multicollinearity

\begin{tabular}{lll}
\hline Variables & Tolerance & VIF \\
\hline STR & 0.820 & 1.220 \\
TDR & 0.806 & 1.240 \\
Size & 0.618 & 1.618 \\
Tangibility & 0.627 & 1.594 \\
Growth & 0.931 & 1.074 \\
Risk & 0.875 & 1.142 \\
\hline
\end{tabular}

Source: Researcher's Stata version 15 Computation

Table 4 shows that there is no correlation between independent variables used for the panel data regression. The existence of multicollinearity would not affect the way in which the regression is performed but rather affect the interpretation of the result (Anderson, Sweeney \& Williams, 2009). The tolerance levels (TL) and the Variance Inflation Factor (VIF) are used to measure the presence of correlation between the independent and control variables. A tolerance level should not be lower than 0.10 while the VIF should not be greater than 10 . All the variables have tolerance levels above 0.10 and the VIF lower than 10. The highest VIF was STR with a VIF of 1.618, indicating that there was no multicollinearility problems within the independent variables used for the analyses.

The study used Hausman test to test endogeneity assumption and the result presented in Table 5. One advantage in the use of panel data over only cross-sectional or time series data is that fixed effects estimator can deal with the unobserved individual hetegeneity. Therefore, the right specification of the model to be used is of great importance in order to obtain consistent results. Endogeneity is a situation where an independent variable is correlated with the error term. Hausman test diagnostic tool used to decide the suitability between the random effects estimator and fixed effect estimator to be used for analysis. The fixed effect estimator allows for heterogeneity or individual differences for the 17 selected companies to have their own intercept value. While the random effect estimator means all the 17 selected companies have a common intercept value. The null hypothesis for the Hausman test is that the preferred model is random effect estimator and the alternate hypothesis is the fixed effect estimator (Greene, 2012). The null hypothesis indicates that is no correlation between the error terms and the independents in the panel data model while the alternative hypothesis indicates that there is correlation between the error terms and the independent variables in the model used for the analysis. The choice for deciding the suitable model is based on the assumption that when the p-value is less than 5\% then we will reject the null hypothesis (i.e., random effect estimator) and used the alternate hypothesis (i.e., fixed effect estimator) for the analysis. This implies that when p-value is greater than 5\% (i.e., p-value) then fixed effect estimator will be used for the analysis.

Table 5. Test Results from Hausman Test

\begin{tabular}{llll}
\hline Models & Chi-Square (5). Statistics & P-value & Test Results \\
\hline Model (1) & 5.40 & 0.369 & Random effects model \\
Model (2) & 14.36 & 0.014 & Fixed effects model \\
\hline
\end{tabular}

Source: Researcher's Stata version 15 Computation

The outcome of the test on model (1) reveals than the p-value is greater than $5 \%$. Since the p-value $>0.05$, the study failed to reject the null hypothesis and conclude that the prefer model estimator for model (1) is random effect estimator. The outcome of the test on model (2) showed that the p-value is less than $5 \%$. Since the p-value $<0.05$, the study rejects the null hypothesis and concludes that there is fixed effect estimator for the model (2).

Table 6. Model Summary

\begin{tabular}{lllll}
\hline \multirow{2}{*}{ Models } & \multicolumn{4}{c}{ Model summary: $\left(\mathrm{R}^{2}\right)$} \\
& Within & Between & Overall & P-value \\
\hline Fixed Effect Estimator: Model (1) & 0.791 & 0.624 & 0.749 & 0.000 \\
Random Effect Estimator: Model (2) & 0.789 & 0.752 & 0.778 & 0.000 \\
\hline
\end{tabular}

Source: Researcher's Stata version 15 Computation 
The main purpose of this this study is to estimate the effect of capital structure on firms' performance using panel data regression to examine the relationship. The $\mathrm{R}^{2}$-within is the predictive power for the Panel data regression analysis and is used to determine the predictive power of the independent variables on the dependent variables. The higher the $\mathrm{R}^{2}$-within, the better the predictive power of the model and should be closer to 1.0 , the better the model. The "rho" gives the proportion of the variation in the dependent variable that cannot be explained by the model.

Table 6 shows the within, between and overall for the $\mathrm{R}^{2}$-summary of the models. The $\mathrm{R}^{2}$-within on the whole can explain and predict about $79.1 \%$ of the variation in ROE for the relationship of STR in model (1). The p-value of less than $5 \%$, (i.e., $\mathrm{p}$-value $<0.05$ ) implies that the model (1) is a good fit for the data. While, the $\mathrm{R}^{2}$-within for the model (2) explains and predicts about $78.9 \%$ of the variation in ROE for the relationship of TDR. A critical look at the statistical significance of the fixed effect estimator used to analyse model (1) revealed that the p-value was 0.000 in Table 6.

Table 7. The Fixed Effect Estimator Result

\begin{tabular}{lllcl}
\hline ROE & Coefficients & Std. Error & t-statistics & P-value \\
\hline STR & -0.122 & 0.0061 & -20.04 & 0.000 \\
Size & -0.015 & 0.0368 & -0.42 & 0.676 \\
Tangibility & 0.222 & 0.0694 & 3.20 & 0.002 \\
Growth & 0.041 & 0.0163 & 2.53 & 0.013 \\
Risk & 0.003 & 0.0038 & 0.66 & 0.513 \\
Constant & 0.028 & 0.0370 & 0.75 & 0.457 \\
Sigma_u & 0.0768 & & & \\
Sigma_e & 0.1045 & & & \\
rho & 0.3504 (fraction of variance due to u_i) & & \\
\hline
\end{tabular}

Source: Researcher's Stata version 15 Computation

Table 7 provides the empirical evidence from the coefficients of the variables used for panel data regression using the fixed effect estimator. The result shows there is negative relationship between the capital structure (i.e., STR) and the firm's performance (i.e., ROE) at 5\% alpha level. The result implies that $1 \%$ in increase STR will lead to $0.122 \%$ decrease in the ROE. The "rho" implies $35.04 \%$ of the variance is due to differences across panels. In view of this, the study failed to reject the null hypothesis for model (1) and therefore, concludes that STR has a significant relationship or influence on the firm's performance. The results from the fixed effect estimator can be below:

ROE $=0.028-0.122$ STR -0.015 Size +0.222 Tangibility +0.041 Growth +0.003 Risk......(1)

Table 8. The Random Effect Estimator Result

\begin{tabular}{lllcl}
\hline ROE & Coefficients & Std. Error & t-statistics & P-value \\
\hline TDR & -0.123 & 0.0059 & -20.83 & 0.000 \\
Size & 0.044 & 0.0289 & 1.52 & 0.129 \\
Tangibility & 0.144 & 0.0535 & 2.69 & 0.007 \\
Growth & 0.043 & 0.0163 & 2.64 & 0.008 \\
Risk & 0.007 & 0.0031 & 2.21 & 0.027 \\
Constant & 0.066 & 0.0311 & 2.14 & 0.032 \\
Sigma_u & 0.0340 & & & \\
Sigma_e & 0.1034 & & & \\
rho & 0.0973 (fraction of variance due to u_i) & & \\
\hline
\end{tabular}

Source: Researcher's Stata version 15 Computation

Table 8 shows the coefficients of the variables obtained from panel data regression of random effect estimator and showed that TDR has a negative relationship between the capital structure (i.e., TDR) and the firm's performance (i.e., ROE) at 5\% alpha level. The results of the random effect estimator used to analyse model (2) revealed that 
independent variables were statically significant on the dependent variable since the p-value was less than $5 \%$ of alpha level (i.e., p-value <.05). This implies that the model (2) is a good fit for the data. The "rho" implies $9.73 \%$ of the variance is due to differences across panels.

Table 8 showed that there is negative relationship between the capital structure (i.e., TDR) and the firm's performance (i.e., ROE) and at 5\% alpha level. It implies that $1 \%$ in increase STR will lead to $0.123 \%$ decrease in the ROE. In view of this, the study failed to reject the null hypothesis for model (2) and therefore, concludes that TDR has a significant relationship or influence on the firm's performance. The results from the random effect estimator can be below:

\section{ROE $=0.066-0.123 T D R+0.044$ Size +0.144 Tangibility +0.043 Growth +0.007 Risk......(2)}

This results from models (1) and (2) are consistent with pecking order theory that postulated that firms raise capital according to a ladder of preference, starting from internally generated funds then externally generated funds in which debt capital is preferred to equity capital.

It is important to note from Table 1 that STR accounted for $67 \%$ of capital used to finance the operation. Also, STR accounted substantially in the Total debt of $76.3 \%$, and that LTR contributed only $9.3 \%$ to the TDR. The study can deduce that only $23.7 \%$ of the capital used is equity capital. Therefore, STR is the most important capital influencing the capital structure decisions of these firms for the period under study. This finding is consistent with the pecking order theory that suggests that managers prefer to raise capital from a source that requires least control or information (Nenu, Ventila \& Ghergbina, 2018).

\section{Conclusions and Recommendations}

One important function of managers in organisational decision making is capital structure decision. The results from models (1) and (2) reveal that capital structure has negative relationship with firms' performance. For every GH $\not 1$ increase in debt capital, the firm's ROE deceases by GH $₫ 0.122$ and GH $\not 0.123$ for STR and TDR respectively. This negative relationship between capital structure and firms' performance is consistent with several studies that challenge the traditional trade-off theory on optimum capital level argued that debt capital are introduced to maximise the shareholders' value or minimises. Pecky order theory has supported the negative relationship between short-term debt and long term debt on previous studies on transition countries by (Abor, 2007; Le \& Phan, 2017; Nenu, Vintila \& Gherghina, 2018; Zeitun \& Tian, 2007).

Other capital structure theorists such as pecking order theory, agency theory, and market signal theory have all challenged the traditional trade-off theory on the reason that debt capital is introduced into capital structure as behavioural characteristics because lesser control and information are required as in the case of pecking order, as a means to boost managers career ambition as the case of agency theory through information asymmetry, adverse selection and moral hazard. Frank and Goyal (2003), Nenu, Ventila and Gherghina (2018) and Tong and Green (2005) have all concluded that capital structure affects firm's performance negatively and therefore, managers should use debt capital to finance operation cautiously. The results implied that firms should minimise the use of debt capital and rather increase the percentage of equity capital in their capital structure mix. Additionally, the study concludes that the results are consistent with pecking order theory, agency theory, and market signal theory.

The study recommends that will improve the performance of the firms listed on the GSE. Firstly, the control variables such as tangibility, growth and risk are all positively correlated with firm's performance. It means that firms should invest in tangible assets that will generate higher firms. Additionally, the firms should expand sales in order to enjoy higher returns. Furthermore, owners of firms should be aware that agency theory, pecking order theory and market signal theory have all challenged optimum capital structure and advocate that managers raise debt capital for other reasons such as sources of capital that requires least information.

Finally, the owners of firms should question the basis of some of capital structure decisions made by managers of firms as advocated, as there could be conflict of interest in some of the decisions made by managers as advocated by agency cost theory. Owners should monitor some of the capital structure decisions made by managers. This can be done by owners questioning the decisions behind the kinds of capital employed by managers to finance the business at the annual general meetings. This will then minimise information asymmetry, adverse selection and moral hazard associated with agency theory.

\section{References}

Abeywardhana, D.K.Y. (2017). Capital structure theory: An overview. Accounting and Finance Research, 6(2), 133-138. https://doi.org/10.5430/afr.v6n1p133 
Abor, J. (2005). The effect of capital structure on profitability: empirical analysis of listed $\quad$ firms $\quad$ in $\quad$ Ghana. Journal of Risk Finance, 6(5), 438-45. https://doi.org/10.1108/15265940510633505

Abor, J., \& Biekpe, N. (2009). How do we explain the capital structure of SMEs in sub-Saharan Africa? Evidence from Ghana, Journal of Economic Studies, 36(1), 83-97. https://doi.org/10.1108/01443580910923812

Akinyomi, O. J., \& Adebayo, O. (2013). Determinants of Capital Structure in Nigeria. International Journal of Innovation and Applied Studies, 3(4), 999-1005

Altman, E. (2015). A further investigation of the bankruptcy cost equation. Journal of Finance, 39(1), 1067-1089. https://doi.org/10.1111/j.1540-6261.1984.tb03893.x

Anderson, D. R., Sweeney, D.T., \& Williams, T.A. (2009). Statistics for Business and Economics. New York: West Publishing Company.

Baker, M. J., \& Wurgler, J. (2002). Market timing and capital structure. The Journal of Finance, 57(1), 1-32. https://doi.org/10.1111/1540-6261.00414

Barclays, M.J., \& Smith, C.W. (1999). The capital structure puzzle: another look at the evidence. Journal of Applied Corporate Finance, 12(1), 8-20. https://doi.org/10.1111/j.1745-6622.1999.tb00655.x

Bevan, A., \& Dandbolt, J. (2002). Capital Structure and its determinants in the UK: A decompositional analysis. Applied Financial Economics, 12(1), 159-170. https://doi.org/10.1080/09603100110090073

Butler, A. W. \& Grullon, G., \& Weston, J. P. (2005). Can Managers Forecast Aggregate Market Returns? Journal of Finance, 60(2). https://doi.org/10.1111/j.1540-6261.2005.00752.x

Cassar, G. (2004). The financing of business start-ups. Journal of Business venturing, 19(1), 261-283. https://doi.org/10.1016/S0883-9026(03)00029-6

Chen, S., \& Chen, J. (2012). Corporate governance and capital allocations of diversified firms. Journal of Banking \& Finance, 36(1), 395-409. https://doi.org/10.1016/j.jbankfin.2011.07.013

Fama, E., \& French, K. (2002). Testing trade-off theory and pecking order predictions about dividends and debt. Review of Financial Studies. https://doi.org/10.1093/rfs/15.1.1

Fama, E.F., \& French, K.R., (1998). Taxes, financing decisions, and firm value. Journal of Finance, 53, 819-843. https://doi.org/10.1111/0022-1082.00036

Flannery, M. J., \& Rangan, K. P. (2006). Partial Adjustment toward Target Capital Structures. Journal of Financial Economics, 79(1). https://doi.org/10.1016/j.jfineco.2005.03.004

Frank, M. Z., \& Goyal, V. K.. (2003). Testing the Pecking Order Theory of Capital Structure. Journal of Financial Economics, 67(1). https://doi.org/10.1016/S0304-405X(02)00252-0

Graham, J. R. \& Harvey, C. R. (2001). The Theory and Practice of Corporate Finance: Evidence from the Field. Journal of Financial Economics, 60(1). https://doi.org/10.1016/S0304-405X(01)00044-7

Greene, W. H. (2012). Econometric Analysis, Pearson, Boston: London.

Hamid, M.A., Abdullah, A., \& Kamaruzzaman N.A. (2015). Capital Structure and Profitability in Family and Non-Family Firms: Malaysian Evidence. Procedia Economics and Finance, 31(1), 44-55. https://doi.org/10.1016/S2212-5671(15)01130-2

Hutchinson, P., Hall, G., \& Chittenden, F. (1995). Small Firm Growth, Access to Capital Markets and Financial Structure: Review of Issues and an Empirical Investigation. Small Business Economics, 8(1), 59-67. https://doi.org/10.1007/BF00391976

Iavorskyi, M. (2013). The impact of capital structure on form performance: Evidence from Evidence from Ukraine. Unpublished master's thesis, Kyiv School of Economics, Ukraine.

Jensen, M. (1986). Agency Costs of Free Cash Flow, Corporate Finance and Takeovers. American Economic Review, $76(2)$.

Modigliani, F., \& Miller, M. (1958). The cost of capital, corporation finance and the theory of investment. The American Economic Review, 48(3), 261-297.

Modigliani, F., \& Miller, M. H. (1963). Corporate income taxes and the cost of capital: A correction. The American Economic Review, 53(3), 433-443. 
Mostafa, H. T., \& Boregowda, S. (2014). A Brief Review of Capital Structure Theories. Research Journal of Recent Sciences, 3(10), 113-118.

Muritala, A. T. (2012). An Empirical Analysis of Capital Structure on Firms' Performance in Nigeria. International Journal of Advances in Management and Economics, 115- 124.

Mwangi, L. W., Makau, M. S., \& Georgr, K. (2014). Relationship between capital structure and performance of nonFinancial Companies listed in the Nairobi Securities Exchange. Global Journal of Contemporary Research in Accounting, Auditing and Business Ethic, 1 (2).

Nenu, E.A., Vintila, G., \& Gherghina, S.C. (2018). The impact of capital structure on risk and firm performance: Empirical Evidence for the Bucharest Stock Exchange Listed Companies. International Financial Studies, 6(41), 1-29. https://doi.org/10.3390/ijfs6020041

Ogebe, P., Ogebe, J., \& Alewi, K. (2013). The Impact of Capital Structure on Firms' Performance in Nigeria, Munich Personal RePEc Archive, Working paper No. 47173. https://doi.org/10.2139/ssrn.2266916

Onaolapo, A.A., \& Kajola, S.O. (2010). Capital Structure and the Firm Performance: Evidence from Nigeria. European Journal of Economics, Finance and Administrative Sciences, 25, 70-82.

Pandey, I.M. (2007). Financial Management. (7th ed.), Vikas Publishing House Pvt Ltd, New Delhi, India.

Park, K., \& Jang, S. (2014). Hospitality and managerial accounting research. Suggesting and interdisciplinary research agenda. International Journal of Contemporary Hospitality Management, 26(5), 751-777. https://doi.org/10.1108/IJCHM-12-2013-0554

Saunders, A., \& Cornett, M.M. (2004). Financial Markets and Institutions: A Modern Perspective. (2nd ed.). Boston: McGraw-Hill.

Sheikh, N. A., \& Wang, Z. (2010). Financing Behavior of Textile Firms in Pakistan. International Journal of Innovation, Management and Technology, 1(2), 130-135.

Titman, S. \& Wessels, R. (1988). The Determinants of Capital Structure Choice. The Journal of Finance, 43(1). https://doi.org/10.1111/j.1540-6261.1988.tb02585.x

Tong, G. \& Green, C. J. (2005). Pecking-Order or Trade-Off Hypothesis? Evidence on the Capital Structure of Chinese Companies. Applied Economics, 37(1). https://doi.org/10.1080/00036840500319873

Yegon, C. Cheruiyot, J. Sang, J., \& Cheruiyot, P.K. (2014). The effects of capital structure on firm's profitability: Evidence from Kenya banking sector. Research Journal of Research and Accounting, 5(9), 152-159.

Zeitun, R., \& Tian, G. (2007). Capital structure and corporate performance: Evidence from Jordan. Australasian Accounting. Business and Finance Journal, 1(1), 40-61. https://doi.org/10.14453/aabfj.v1i4.3 